\title{
THE SWEAT TEST IN THE DIAGNOSIS OF FIBROCYSTIC DISEASE OF THE PANCREAS
}

\author{
BY \\ ETHEL FINCH \\ From the Department of Pathology, Children's Hospital, Sheffield
}

(RECEIVED FOR PCBLICATION SEPTEMBER 3, 1956)

The sweat test for the diagnosis of fibrocystic disease of the pancreas owes its origin to an observation made during the heat wave of 1948 in New York (Kessler and Andersen, 1951) that more than half of the children admitted to hospital with signs of heat prostration were cases of fibrocystic disease of the pancreas. Although the serum sodium and chloride concentrations were much reduced the children had no history of prolonged vomiting, intestinal loss, kidney or adrenal dysfunction. It was postulated that there was some derangement of the sweating mechanism and that excessive electrolyte loss may have occurred through the skin.

In 1953 a preliminary report was published of the sodium and chloride concentrations in the sweat from eight patients with fibrocystic disease of the pancreas together with those from a similar number of control patients of the same age group (Darling, di Sant'Agnese, Perera, and Andersen). This showed that the former group excreted four to five times as much sodium and chloride in the sweat as did the controls. Di Sant'Agnese, Darling, Perera, and Shea (1953) later published a much larger series of results which have confirmed the earlier findings of the persistently high concentration of sodium and chloride in the sweat of patients with fibrocystic disease of the pancreas.

The purpose of this communication is to report a similar series of investigations done in Sheffield Children's Hospital. An attempt is also made to compare the value of the sweat test with that of other laboratory tests usually performed on patients with steatorrhoea, failure to thrive, and chronic respiratory lesions.

\section{Methods}

The Sweat Test.-A modification by Shwachman, Higgins, and Dooley (1954) of Darling's (1948) method was used.

Sweat is collected by applying a pad of gauze about 3 in. square (washed in distilled water and dried) to the lower part of the patient's back. which has previously been washed with distilled water and dried. The gauze is covered with a piece of waterproof plastic material held in place with adhesive tape. It is important that the gauze should be handled with rubber gloves to prevent contamination from the skin of the person performing the test.

The body of the patient is enveloped in a plastic bag (the type used for storing clothes and obtainable in a variety of sizes) which is secured on the shoulders by tying with tape or bandage.

After wrapping well in a blanket, the child is put in a cot in a cubicle maintained at $80^{\circ}-85^{\circ} \mathrm{F}$. After one and a half to two hours, during wh:ch time the child should sweat freely, the sweat-soaked gauze is transferred to a stoppered flask which has previously been weighed with the dry gauze. The flask and gauze are reweighed and thus the amount of sweat is found.

A known volume of distilled water (usually between 20 and $40 \mathrm{ml}$. is sufficient) is added. and the sweat leached out. Sodium is estimated by means of the flame photometer and chlorides by any suitable method.

The results are expressed in m.Eq. /litre.

A minimum of $0.5 \mathrm{~g}$. sweat is required.

The Lipiodol Test (Silverman and Shirkey. 1955).-Dietary restriction is not necessary, but pancreatic enzyme therapy must be stopped for at least 48 hours before the test. A sample of urine is obtained before giving the patient lipiodol.

Dose of Lipiodol.--For patients weighing $10-20 \mathrm{~kg}$. the dose is $0.5 \mathrm{ml}$. $/ \mathrm{kg}$. Not less than $5 \mathrm{ml}$. and not more than $10 \mathrm{ml}$. should be given.

Samples of urine to be tested for iodine are obtained at 12.18, and 24 hours after the administration of lipiodol. However, if there is difficulty in collection. one specimen of urine taken between 12 and 18 hours is sufficient.

Urine samples are diluted $1: 1,1: 2$ up to $1: 16$. After acidification with $8 \mathrm{~N}$ nitric acid, the samples are tested for iodine with freshly prepared $1 \%$ starch. A blue colour persisting for five minutes is regarded as positive.

Normally, iodine is present in at least four of the dilutions and usually in all six. Urines from patients with fibrocystic disease of the pancreas show either no iodine or a trace in the first and second tubes. 
It has been found that debilitated children who have an acute or chronic illness can give negative results, but after recovery from their illness they show normal function. This test therefore only excludes fibrocystic disease.

Faecal and Duodenal Trypsin.-The gelatine tube method was used (Emery, 1952).

Fat Balance Tests.-Three- or five-day collections of food and faeces were examined for fat content. Fat was estimated by Cammidge's (1914) method.

\section{Material}

During the year March, 1955, to March, 1956, nine patients between the ages of 2 weeks and 7 years with fibrocystic disease of the pancreas were available for study. In five, the diagnosis was made on the clinical assessment supported by the laboratory findings of absent or low duodenal trypsin, and the presence of large amounts of neutral fat in the stools with low fat absorption. In the other four cases the diagnosis was made on clinical grounds supported by the lipiodol test, and also the trypsin activity of the faeces.

Control patients included those with steatorrhoea, failure to thrive, and chronic respiratory lesions. The diagnosis of fibrocystic disease of the pancreas was ruled out in these patients either by the presence of faecal and duodenal trypsin in normal amounts or by a lipiodol test and/or normal fat absorption.

\section{Results}

Table I shows the range of concentration of sodium and chloride in 12 samples of sweat from nine patients with fibrocystic disease together with 40 samples from control patients. Fig. 1 gives the distribution of these figures.

TABLE I

CONCENTRATIONS OF SODIUM AND CHLORIDE

\begin{tabular}{|c|c|c|c|}
\hline Pancreatic Fibrosis & & $\mid \begin{array}{c}\text { Range } \\
\text { (m.Eq./Litre) }\end{array}$ & Mean Value \\
\hline $\begin{array}{c}12 \text { Tests in Patients } \\
\text { Sweat sodium } \ldots \\
\Rightarrow \text { chlorides } \ldots \\
\text { 40 Tests in Controls }\end{array}$ & $\because$ & $\begin{array}{l}86-128 \\
85-138\end{array}$ & $\begin{array}{l}108 \\
110\end{array}$ \\
\hline $\begin{array}{c}\text { Sweat sodium } \\
, y \\
\text { chlorides }\end{array}$ & $\therefore$ & $\begin{array}{l}7 \cdot 7-76 \\
\text { Trace-39 }\end{array}$ & $\begin{array}{l}28 \cdot 3 \\
15 \cdot 4\end{array}$ \\
\hline
\end{tabular}

The highest sodium concentration of the sweat in control patients is $76 \mathrm{~m} . \mathrm{Eq}$./litre, with an average concentration of $28.3 \mathrm{~m}$.Eq./litre, whilst the lowest sodium concentration in the sweat from patients with fibrocystic disease of the pancreas is $86 \mathrm{~m}$. Eq./litre, with a mean level of $108 \mathrm{~m} . \mathrm{Eq}$./ litre.

Similarly, the highest chloride concentration of the sweat in the control series is $39 \mathrm{~m} . \mathrm{Eq}$./litre and the mean value $15.4 \mathrm{~m} . \mathrm{Eq}$./litre, whilst the
SWEAT ELECTROLYTES.

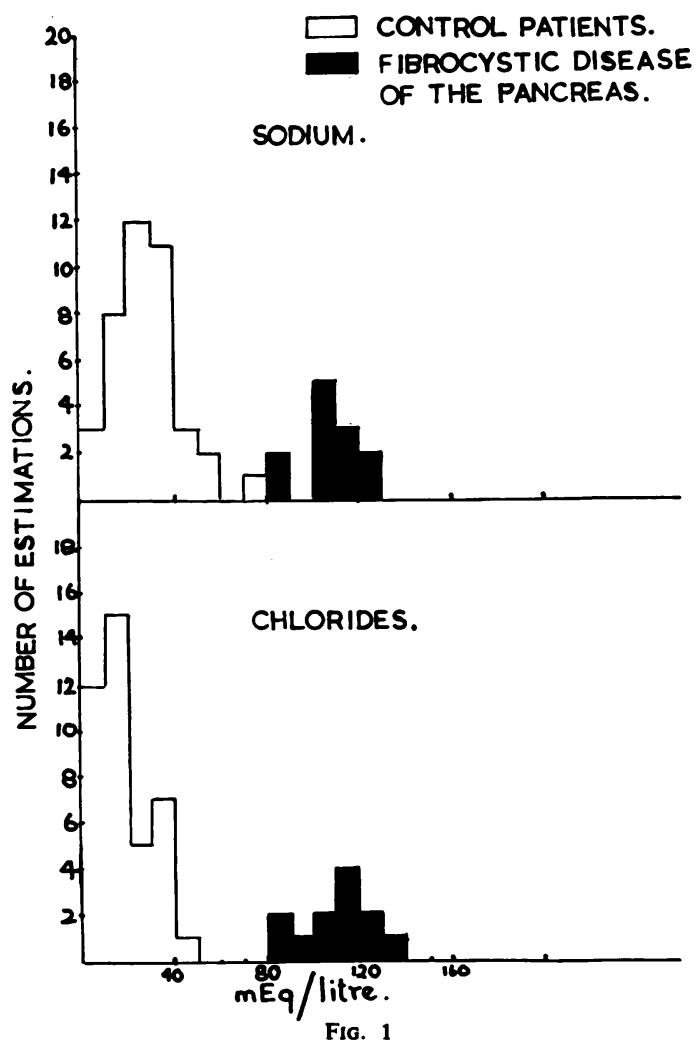

lowest chloride concentration of the sweat in patients with fibrocystic disease of the pancreas is $85 \mathrm{~m} . \mathrm{Eq}$./litre, with a mean value of $110 \mathrm{~m} . \mathrm{Eq}$./ litre.

TABLE II

RESULTS OF TESTS IN CONTROL SERIES

\begin{tabular}{|c|c|c|c|c|c|c|c|c|}
\hline & \multirow{2}{*}{$\begin{array}{l}\text { Age } \\
\text { in } \\
\text { Years }\end{array}$} & \multicolumn{2}{|c|}{ Fat Balance } & \multicolumn{2}{|c|}{$\begin{array}{l}\text { No. Tubes } \\
\text { Positive for } \\
\text { Trypsin }\end{array}$} & \multirow{2}{*}{$\begin{array}{c}\text { No. } \\
\text { Tubes } \\
\text { Posi- } \\
\text { tivefor } \\
\text { Lip- } \\
\text { iodol }\end{array}$} & \multicolumn{2}{|c|}{$\begin{array}{c}\text { Sweat } \\
\text { Electrolytes } \\
\text { (m.Eq./Litre) }\end{array}$} \\
\hline & & $\begin{array}{c}\text { Output } \\
\text { per Day } \\
\text { (g.) }\end{array}$ & $\mid \begin{array}{c}\% \text { Ab- } \\
\text { sorp- } \\
\text { tion }\end{array}$ & Faecal & $\begin{array}{l}\text { Duo- } \\
\text { denal }\end{array}$ & & $\mathrm{Na}$ & $\mathrm{Cl}$ \\
\hline K.W... & $4 / 12$ & & 87 & & 10 & 6 & $17 \cdot 8$ & $18 \cdot 2$ \\
\hline 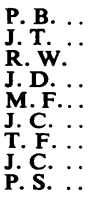 & $\begin{array}{c}2 \frac{1}{2} \\
1 \frac{1}{2} \\
6 \frac{1}{2} \\
1 \frac{1}{2} \\
4 \\
13 / 12 \\
2 \frac{1}{2} \\
1112 \\
4\end{array}$ & $\begin{array}{l}1.9 \\
3.7 \\
1.6 \\
1.6 \\
1.7 \\
1.0 \\
1.5 \\
1.5 \\
2.3\end{array}$ & $\begin{array}{l}94 \\
91 \\
97 \\
95 \\
97 \\
97 \\
96 \\
96 \\
93\end{array}$ & $\begin{array}{r}8 \\
9 \\
7 \\
4 \\
8 \\
10\end{array}$ & 9 & $\begin{array}{l}6 \\
6 \\
6 \\
6\end{array}$ & $\begin{array}{l}25.0 \\
26.0 \\
19.6 \\
39.0 \\
30.0 \\
26.0 \\
22.0 \\
34.0 \\
41.0\end{array}$ & $\begin{array}{l}14.4 \\
\text { Trace } \\
13.6 \\
31.0 \\
31.0 \\
15.0 \\
17.0 \\
30.0 \\
20.6\end{array}$ \\
\hline
\end{tabular}

L.I. = low fat intake.

Table II gives the result of fat balance tests, faecal and duodenal tryptic activity, lipiodol tests, and concentration of sodium and chloride in sweat from 10 control patients. 
TABLE III

RESULTS OF TESTS IN PATIENTS

\begin{tabular}{|c|c|c|c|c|c|c|c|c|}
\hline & \multirow{2}{*}{\begin{tabular}{|} 
Age \\
in \\
Years
\end{tabular}} & \multicolumn{2}{|c|}{ Fat Balance } & \multicolumn{2}{|c|}{$\begin{array}{l}\text { No. Tubes } \\
\text { Positive for } \\
\text { Trypsin }\end{array}$} & \multirow{2}{*}{$\begin{array}{l}\text { No. } \\
\text { Tubes } \\
\text { Posi- } \\
\text { tivefor } \\
\text { Lip- } \\
\text { iodol }\end{array}$} & \multicolumn{2}{|c|}{$\begin{array}{c}\text { Sweat } \\
\text { Electrolytes } \\
\text { (m.Eq. Litre) }\end{array}$} \\
\hline & & $\begin{array}{l}\text { Output } \\
\text { per Day } \\
(\mathrm{g} .)\end{array}$ & $\begin{array}{l}\% \text { Ab- } \\
\text { sorp- } \\
\text { tion }\end{array}$ & Faecal & $\begin{array}{l}\text { Duo- } \\
\text { denal }\end{array}$ & & $\mathrm{Na}$ & $\mathrm{Cl}$ \\
\hline $\begin{array}{l}\text { B. S. . } \\
\text { S. B. } \\
\text { Y. E. } \\
\text { F.St. C. } \\
\text { L. K. . }\end{array}$ & $\begin{array}{c}2 \\
3 \\
11 \\
1 \frac{1}{2} \\
2 \frac{1}{2}\end{array}$ & $\begin{array}{r}5.7 \\
15.8 \\
17.0 \\
7.6 \\
6.8 \\
\end{array}$ & $\begin{array}{l}\text { Coel } \\
86 \\
70 \\
47 \\
75 \\
80 \\
\end{array}$ & $\begin{array}{c}\text { iac dise } \\
1 \\
9 \\
6 \\
8\end{array}$ & $\begin{array}{r}7 \\
7 \\
9\end{array}$ & $\begin{array}{l}6 \\
6 \\
0\end{array}$ & $\begin{array}{l}17 \cdot 6 \\
29 \cdot 6 \\
11 \cdot 2 \\
45 \cdot 5 \\
27 \cdot 4 \\
\end{array}$ & $\begin{array}{l}\text { Trace } \\
10 \\
\text { Trace } \\
31.5 \\
23.0 \\
\end{array}$ \\
\hline $\begin{array}{l}\text { J. S. } \\
\text { K. H. } \\
\text { J. W. } \\
\text { S.P. } \\
\text { D. W. }\end{array}$ & $\begin{array}{l}2 \\
1 \\
2 \frac{1}{2} \\
2812\end{array}$ & \begin{tabular}{|c} 
Fibrocy \\
21.5 \\
6.0 \\
4.5 \\
16.0 \\
22.6
\end{tabular} & $\begin{array}{l}\text { ystic dis } \\
66.5 \\
84.0 \\
80.0\end{array}$ & $\begin{array}{c}\text { ease of } \\
4 \\
3 \\
0 \\
0 \\
8\end{array}$ & $\begin{array}{l}\text { the pan } \\
0 \\
1 \\
0 \\
2\end{array}$ & $\begin{array}{l}0 \\
1 \\
0\end{array}$ & $\begin{array}{r}110 \\
102 \\
117 \\
86 \\
128\end{array}$ & $\begin{array}{r}94 \\
116 \\
122 \\
102 \\
128\end{array}$ \\
\hline
\end{tabular}

Table III gives the results of fat balance tests, faecal and duodenal tryptic activity, lipiodol tests, and concentration of sodium and chloride in the sweat from 10 patients with steatorrhoea, i.e., five patients with coeliac disease and five with fibrocystic disease of the pancreas.

The fat balance tests on the patients with steatorrhoea show the typical high fat output with low percentage absorption compared with the control group. Faecal and duodenal tryptic activity in patients with coeliac disease is comparable with that of the control patients, while the children with fibrocystic disease of the pancreas show, on the whole, less tryptic activity. Similarly, the lipiodol tests performed on patients with coeliac disease show the same degree of lipase activity as do the control series, whereas those on patients with fibrocystic disease of the pancreas show none or only slight lipase activity.

The sodium and chloride concentrations of the sweat of the control patients and those with steatorrhoea fall in the same range, whereas those from the patients with fibrocystic disease are four to five times as high as these other two groups.

\section{Discussion}

All of the nine cases of fibrocystic disease that we examined showed a persistently high level of sweat sodium and chloride content. These levels were beyond any found in the normal series. The findings confirm completely those made by di Sant'Agnese et al.

We found no relationship between the degrees of pancreatic and pulmonary involvement and the levels of sweat electrolytes. The same high levels were shown in the sweat from two cases of meconium ileus at 6 and 8 weeks of age respectively, as in the older well-developed cases. This again confirms the findings of the American workers (di Sant'Agnese et al., 1953).

The possible cause of this electrolyte abnormality of sweat in the fibrocystic syndrome has been discussed at length by di Sant'Agnese (1955). This abnormality would appear to be an inherited factor, for some parents of affected children show similar high sweat sodium and chloride concentrations, but it is not known if these parenis have been affected in this way throughout the whole of their lives (Shwachman, 1955).

Our findings suggest that the occurrence of high sweat electrolyte concentrations together with relevant clinical features is diagnostic for fibrocystic disease of the pancreas.

Patients with adrenal insufficiency may have high sweat electrolytes, but these revert to normal or subnormal levels on treatment with D.O.C.A. or A.C.T.H. (Conn, 1949). Neither of these drugs has any significant effect on the sweat electrolytes in fibrocystic disease (di Sant'Agnese, 1955).

The value of this test is twofold: it appears to give the same results at all stages of the disease and can be carried out whilst the patient is on pancreatin therapy.

\section{Conclusions}

(1) From the data already acquired it appears that sweat sodium above $80 \mathrm{~m} . \mathrm{Eq}$./litre, and chlorides above $60 \mathrm{~m} . \mathrm{Eq}$./ /itre, together with relevant clinical data, are diagnostic of fibrocystic disease of the pancreas.

(2) It is the only test which gives similar results at any stage of the disease.

(3) It is the only test in which results are not invalidated if the patient is receiving pancreatin therapy.

I would like to thank the nursing staff of the hospital for the collection of sweat from the patients, and Drs. J. L. Emery and J. C. Haworth for their heip and criticism in the writing of this paper.

$$
\text { REFERENCES }
$$

Cammidge, P. J. (1914). The Faeces of Children and Adults. Wright, Bristol.

Conn, J. W. (1949). Arch. intern. Med., 83, 416.

Darling, R. C. (1948). Arch. phys. Med., 29, 150.

- di Sant'Agnese, P. A., Perera, G. A., and Andersen, D. H. (1953). Amer. J. med. Sci., 225, 67.

di Sant'Agnese, P. A. (1955). Report of the 18th Ross Pediatric Research Conference, Ross Laboratories, Columbus, Ohio. Darling, R. C., Perera, G. A., and Shea, E. (1953). Pediatrics, 12, 549 .

Emery, J. L. (1952). Arch. Dis. Childh., 27, 257.

Kessler, W. R., and Andersen, D. H. (1951). Pediatrics, 8648.

Shwachman, H. (1955). Report of the 18th Ross Pediatric Research Conference, Ross Laboratories, Columbus, Ohio.

- Higgins, E., and Dooley, R. R.(1954). Sweat Electrolyies. Read at the Annual Meeting of the American Academy of Pediatrics, Chicago, October, 1954.

Silverman, F. N., and Shirkey, H. C. (1955). Pediatrics, 15. 143. 